\title{
Changes in nutraceutical quality of tomato under different organic substrates
}

\author{
Manuel Fortis-Hernández ${ }^{1}$; Pablo Preciado-Rangel ${ }^{1}$; Miguel A Segura-Castruita ${ }^{1}$; Leonel Mendoza-Tacuba ${ }^{1}$; \\ Miguel A Gallegos-Robles ${ }^{3}$; José L García Hernández ${ }^{3}$; Cirilo Vásquez-Vásquez ${ }^{3 *}$
}

${ }^{1}$ Technological Institute of Torreon, Coahuila, México; fortismanuel@hotmail.com; ppreciador@yahoo.com.mx; leo_flakillo@hotmial.com; ${ }^{3}$ Agriculture and Animal Science School, (FAZ) Juarez University of the State of Durango (UJED), Durango, Mexico; garoma64@hotmail. com; josel.garciahernandez@yahoo.com; cirvaz60@hotmail.com (*corresponding author); dylims5@hotmail.com

\begin{abstract}
Yield and nutraceutical quality of Sahel tomato cultivar under shade net was evaluated using different mixtures of organic substrates in Coahuila, northern Mexico. The treatments consisted of mixtures using sand (S), vermicompost (VC), solarized bovine manure (SB), agricultural soil (AS) and mineralized compost (MC). The treatments were: T1 (S:VC, 80:20), T2 (S:SB, 80:20), T3 (S:SB:AS, 80:15:05), T4 (S:VC:AS, 80:15:05), T5 (S:MC, 80:20), and a control treatment T6 (S, 100\%) with Steiner solution. Yield results showed that the best organic treatments were T5 and T4 with 3.48 and $3.33 \mathrm{~kg} \mathrm{plant}^{-1}$, respectively; while the highest yield was in control (T6) with $3.71 \mathrm{~kg}$ plant $^{-1}$. The highest phenolic content in the organic treatment of fruits was $56.94 \mathrm{mg}$ equivalent of gallic acid per $100 \mathrm{~g}$ in fresh weight for T5, while the treatment with chemical fertilization obtained 49.82 . The greatest antioxidant capacity was obtained in T4, with $478.34 \mu \mathrm{M}$ equivalent of Trolox/100 $\mathrm{g}$ fresh weight. Two colors were evaluated (yellow and red) corresponding to two ripeness phases. Lycopene content in tomatoes was in average $32 \%$ higher in the red colored fruits than in the yellow ones, with 3.12 and $2.24 \mathrm{mg}$ lycopene 100 g pulp $^{-1}$ values, respectively. For the red ones, treatment T5 showed the highest value (3.52) and in yellow ones T1 reported 2.35, while $\mathrm{T} 2$ presented the lowest values for both colors. Organic fertilizers based on S:VC can induce good amounts of lycopene in fruits of both colors, as well as improve phenols and antiOX.
\end{abstract}

Keywords: Solanum lycopersicum, 1,1 biphenyl, 2-picrilhidrazil, phenols, lycopene.

\section{RESUMO}

Variações na qualidade nutracêutica de tomate cultivado sob diversos substratos orgânicos

Avaliou-se em Coahuila, norte do México, o rendimento e a qualidade nutracêutica da cultivar de tomate Sahel sob malha sombreada. Foram utilizadas diversas misturas de substratos orgânicos consistindo das misturas utilizando areia (S), vermicomposto (VC), esterco bovino solarizado (SB), solo agrícola (AS) e composto mineralizado (MC). Os tratamentos foram: T1 (S:VC, 80:20), T2 (S:SB, 80:20), T3 (S:SB:AS, 80:15:05), T4 (S:VC:AS, 80:15:05), T5 (S:MC, 80:20), e um tratamento controle T6 (S, 100\%) com solução de Steiner. Os resultados de produtividade mostraram que os melhores tratamentos orgânicos foram T5 e T4 com 3,48 e 3,33 kg planta $^{-1}$, respectivamente; enquanto o maior rendimento foi obtido no controle com $3,71 \mathrm{~kg}$ planta $^{-1}$. O maior teor fenólico nos frutos sob tratamento orgânico foi de 56,94 mg equivalentes de ácido gálico por $100 \mathrm{~g}$ de peso fresco para T5, enquanto o tratamento com adubação química obteve 49,82. A maior capacidade antioxidante foi obtida em T4, com 478,34 $\mu \mathrm{M}$ equivalente de Trolox/100 g de peso fresco. Foram avaliadas duas fases de amadurecimento nos frutos (amarelo e vermelho). O conteúdo de licopeno no tomate foi, em média, $32 \%$ maior nos frutos de cor vermelha que nos amarelos, com 3,12 e 2,24 $\mathrm{mg}$ de licopeno $100 \mathrm{~g} \mathrm{polpa}^{-1}$, respectivamente. Para os vermelhos, o tratamento T5 apresentou o maior valor $(3,52)$ e nos amarelos T1, 2,35, enquanto o $\mathrm{T} 2$ apresentou os menores valores para as duas cores. Adubos orgânicos à base de $\mathrm{S}: \mathrm{VC}$ podem induzir boas quantidades de licopeno em frutos de ambas as cores, além de melhorar fenóis e antiOX.

Palavras-chave: Solanum lycopersicum, 1,1 bifenil, 2-picrilhidrazil, fenóis, licopeno.

\section{Received on February 13, 2017; accepted on December 11, 2017}

$\mathrm{T}_{\mathrm{i}}$ omato (Solanum lycopersicum) is one of the main vegetables cultivated in protected environments in the world. Mexico is the tenth producing country, its economic importance lies in the great amount of labor it requires, aside of its profitability. This crop along with legumes, fruits and fresh vegetables accounted for about $25 \%$ of the total agricultural exports made in 2014; the state of Coahuila was in the tenth place in production value, while the first five tomato-producing states are Sinaloa, San Luis Potosi, Michoacan, Jalisco and Zacatecas (SAGARPA, 2015).

Production and consumption of this vegetable is important, since it has proven to be good for health due to its components, as vitamins and antioxidants. Tomato has different kinds of antioxidants, such as carotenoids, particularly lycopene, vitamin C, phenols and tocopherols (Mani et al., 2012). However, these amounts may 
vary depending on the species, ripeness and environmental conditions during crop's development. Other researchers (Bunea et al., 2012; Omar et al., 2012) have reported that application of organic manure on crops increases fruit phenolic content and antioxidant capacity. These results may be due to a high content of humic acids (Gutiérrez-Miceli et al., 2007) and low $\mathrm{N}$ content in the organic fertilizers.

Lycopene constitutes over 95.4\% of the total compounds in the red ripeness state and is responsible for its characteristic color (Helyes \& Lugasi, 2006). Lycopene is also very important since it is one of the major antioxidants consumed by humans in a regular diet.

However, few studies have focused on how to increase the amount of this compound in fruits. According LunaGuevara \& Delgado-Alvarado (2014), lycopene content is affected by biotic or environmental factors, among these the mineral nutrition and the growth conditions are determinant.

In this research, the impact of different organic substrates on the phytochemical quality of tomato fruits was studied.

\section{MATERIAL AND METHODS}

The study was conducted under shade net conditions in Technological Institute of Torreon (ITT), Coahuila, México $\left(103^{\circ} 22^{\prime} 33^{\prime \prime} \mathrm{W}, 25^{\circ} 36^{\prime} 36^{\prime \prime}\right.$ $\mathrm{N})$. Climate of this region is dry desert with rainfall in summer and cool winters. Precipitation is $241.9 \mathrm{~mm}$ and annual mean temperature is $21.5^{\circ} \mathrm{C}$, ranging from $33.7^{\circ} \mathrm{C}$ maximum and $7.5^{\circ} \mathrm{C}$ minimum. The used shade house consisted of a metallic structure, $25 \mathrm{~m}$ length, $12 \mathrm{~m}$ width, and $3.0 \mathrm{~m}$ high, covered with anti-aphids mesh (40 x 26 threads $\mathrm{cm}^{-2}$, cal. 0.009). The experiment was conducted in spring-summer 2014 period, using Saladette tomato type, Sahel cultivar (Roger Syngenta). Germination took place in polystyrene trays of 200 cavities, using Peat Moss as substrate. One seed per cavity was deposited, covering it with black plastic until seed germination, with seeding date of February 15, 2014. Sprinkler irrigation was used twice a day to keep the rooting substrate moist. Fertilization based on urea and superphosphate (1260) was applied at a dose of $0.50 \mathrm{~g} \mathrm{~L}^{-1}$; application was made daily at the first irrigation, starting application when $90 \%$ emerged. When plants had an approximate height of $15 \mathrm{~cm}$ and five to six true leaves, they were transplanted placing one seedling per pot, and using $10 \mathrm{~kg}$ black polyethylene bags.

The materials used for filling pots were vermicompost (VC), solarized bovine manure (SB), mineralized compost (MC), agricultural soil (AS) and sand $(\mathrm{S})$ previously sterilized with $5 \%$ sulfuric acid. Chemical analysis was done in accordance with AnsorenaMiner (1994) and characteristics of each one are shown in Table 1. Solarization of the bovine manure was carried out on the ITT field over a three month period reaching temperatures of $70^{\circ} \mathrm{C}$ inside the solarization pile; vermicomposting was obtained from the institution's earthworms (Eisenia foetida) for three months and mineralized compost was bought from an organic supplies provider located in this region. The agricultural soil type was Aridisol (Fluventic haplocambids). Treatments were prepared on volume/volume base (v/v) as follows: T1 (S:VC, 80:20), T2 (S:SB, 80:20), T3 (S:SB:AS, 80:15:05), T4 (S:VC:AS, 80:15:05), T5 (S:MC, $80: 20$ ), and control treatment T6 (S, $100 \%$ ) with Steiner solution (Steiner, 1984).

Irrigation water was used in treatments T1, T2, T3, T4 and T5, applying 1.0 $\mathrm{L} \mathrm{pot}^{-1} \mathrm{day}^{-1}$; in T6, 1.0 L pot $^{-1}$ day $^{-1}$ of nutrient solution. Plants were guided to a single stem and pruning consisted of the elimination of auxiliary buds, additionally tutors were placed on the single stem and guided with raffia to help plants stay in place and hold the fruit's weight.

The number of cuts made was nine and average bunches per treatment were as follows: 9 (T1), 6 (T2), 5 (T3), 8 (T4), 10 (T5) and 8 (T6). The measured variables, considering four fruits pot $^{-1}$ cut $^{-1}$, were: yield $(\mathrm{Y})$, the fruits were harvested taking into consideration its commercial size, for which a Shimadzu digital analytical scale was used, calculating it based on fruits' weight in each replication per treatment. Result was expressed in kilograms per plant $\left(\mathrm{kg} \mathrm{plant}^{-1}\right)$. Fruit length (polar diameter) and fruit width (equatorial diameter) of the four harvested tomatoes were measured, and classified according to the Mexican Official Standard NMXFF-031 (SAGARPA-ASERCA, 2008); this was conducted for each treatment, using a digital Vernier. Soluble solids in the red fruits were measured using a Sper scientific 300001 refractometer.

Determination of AntiOX and phenolic in the red fruits was carried out considering its physiological maturity at grade 5 and according to classification of the Mexico Supreme Quality brand (SAGARPA-ASERCA, 2008). Total antioxidant capacity was determined in Trolox equivalent, antioxidant capacity by the 1,1 biphenyl, 2-picrilhidrazil (DPPH) radical method with some modifications made according to in vitro DPPH method (Molyneux, 2004). The absorbance of the solution was read, adjusting it to a $515 \mathrm{~nm}$ wave length. A standard curve was prepared with Trolox (Aldrich, St. Louis, Missouri, USA), and results were reported as equivalent antioxidant capacity in $\mu \mathrm{M}$ equivalent in Trolox per $100 \mathrm{~g}$ fresh weight ( $\mu \mathrm{M}$ equivalent in Trolox /100 g FW). Analyses were made in triplicate.

Total phenolic compound content was measured based on modification of the Folin-Ciocalteau (Esparza et al., 2006) method. Phenolic content was calculated by a pattern curve using gallic acid (Sigma, St. Louis, Missouri, USA) and results were reported in equivalent gallic acid mg per $100 \mathrm{~g}$ fresh weight (mg equivalent GA/100 g FW). Analyses were made in triplicate.

Fruits that showed red and yellow colors were selected and frozen at $-40^{\circ} \mathrm{C}$ for lycopene analysis, and it was extracted using the modified protocol of Mayeaux et al. (2006). Fruit colors (yellow and red) were analyzed by a Minolta CR-400 tristimulus colorimeter. For lycopene quantification, an Agilent 2100 Series high performance liquid chromatograph (HPLC) was used, where a Supelco Discovery ${ }^{\circledR} \mathrm{C}_{18}(5$ $\mathrm{cm} \times 4.6 \mathrm{~mm}$ and $5 \mu \mathrm{m}$ ) column was installed. To set the operating conditions 
of the chromatograph, the technique reported by Anguelova \& Warthersen (2000) was taken as basis, with different injection speeds and concentrations of the solvents in the mobile phase. A Sigma brand lycopene standard was used, its real concentration was determined by the lycopene molar absorptivity coefficient in hexane. For each experimental unit, lycopene was extracted from tomato pulp and immediately injected to the HPLC. This procedure was conducted three times for each experimental unit. To determine the lycopene concentration in each case, the peak area of the sample was compared to the peak area of the standard; results were reported in $\mathrm{mg}$ lycopene values per $100 \mathrm{~g} \mathrm{pulp}^{-1}$.

The experimental design, used to evaluate the effect of treatments with four replicates each, was completely randomized. Data were analyzed statistically by analysis of variance and means and was separated by the Tukey $(\mathrm{P} \leq 0.05)$ test using software package SAS Version 9.2 (SAS, 2009).

\section{RESULTS AND DISCUSSION}

The evaluated substrates determined the quality components of tomato fruit, since statistical analysis presented significant differences $(\mathrm{P} \leq 0.05)$ between treatments for fruit quality.

The highest average fruit weight was found in the organic treatment T5 (390 g) containing mineral compost, T4 (360 g) containing vermicompost and soil, and T1 (270 g) containing only vermicompost, being statistically equivalent to fruit's weight of T6 Steiner solution control treatment (283 g). The lowest average fruit weights were in treatments T2 and T3 with 140 and 103 $\mathrm{g}$, respectively. Both treatments were mixed with solarized bovine manure (Table 1). Yields found in the organic substrate treatments with average weight of $252.6 \mathrm{~g}$, were above the data reported by Marquez et al. (2008), who, working with vermicompost plus sand and vermicompost plus pearlite treatments, obtained a weight of $238.4 \mathrm{~g}$.

For the polar diameter in organic treatments, the mean values were between 6.4 and $5.3 \mathrm{~cm}$, having the highest values in T5, which contained mineralized compost (S:MC, 80:20). The best organic treatment (T5) was $27.0 \%$ higher than the chemical one; it is worth mentioning that fruits of this treatment are considered medium size. The equatorial diameter did not show significant differences (Table 2). These results are equal to those found by Moreno et al. (2012), who stated that the polar diameter of tomatoes (Miramar and Romina genotypes) using a mixture of earthworm humus and sand was 5.9 to $6.1 \mathrm{~cm}$. Regarding the equatorial diameter, no significant difference was found in this study in a 4 to $4.5 \mathrm{~cm}$ range. De la Cruz et al . (2010) also did not find significant differences when using the compost and earthworm humus mixture in different proportions (100:00; 75:25 and 50:50).

For soluble solids content, according to the means comparison, no significant differences were found between substrates and sand mixtures, or in the control treatments. However, in this study, two treatments (T4 and T6), presented quality fruits in terms of soluble solids (Table 2). According to De la Cruz-Lazaro et al. (2009), tomato for fresh use must have contents over $4.5^{\circ}$ Brix.

According to Zhai et al. (2015), soluble solids increase in tomato as the salinity of the irrigation water increased. In this study, different results were observed since high values of soluble solids were not associated with high electrical conductivity in the organic substrates.

In the mean comparison test for yield per plant, significant statistical differences were found between treatments, highlighting, as expected, the control treatment fertilized with inorganic nutritive solution (T6) with $3.71 \mathrm{~kg} \mathrm{plant}^{-1}$ average. This was statistically equal to treatments T5 (S:MC, 80:20) and T4 (S:VC:AS, $80: 15: 05)$ with values of 3.48 and 3.33 $\mathrm{kg}$ plant $^{-1}$, respectively. These yields were in average, $12 \%$ lower than the control (Figure 1).

On the other hand, the solarized manure treatments in their higher proportion (S:SB, 80:20) and added with soil (S:SB:AS, 80:15:05) presented less than half yields, with respect to the best organic treatment which contains mineralized compost T5 (S:MC, 80:20). These results are lower than those found by Ortega-Martinez et al. (2010) of $4 \mathrm{~kg}$ plant ${ }^{-1}$, using sawdust compost substrates; by De la Cruz-Lazaro et al. (2009) with 4 kg plant $^{-1}$ using sand plus vermicompost (50:50) prepared with bovine manure; and by De la Cruz et al. (2010), with $5.73 \mathrm{~kg}$ plant $^{-1}$ using tezontle and vermicompost and 5.58 $\mathrm{kg}$ plant $^{-1}$ using tezontle and bovine manure in a 65:35 proportion. These three authors used Sun 7705 cultivar.

Total phenolic content and the antioxidant capacity of organic tomatoes

Table 1. Chemical composition (dry weight) of the material used during evaluation of organic substrates for production of tomato under shade net conditions. Coahuila, Mexico, Technological Institute of Torreon, 2014.

\begin{tabular}{|c|c|c|c|c|c|c|c|c|c|c|c|c|}
\hline \multirow{2}{*}{ Material } & $\mathrm{NO}_{3}^{-}$ & $\mathbf{P}$ & $\mathbf{K}$ & $\mathbf{C a}$ & Mg & $\mathbf{F e}$ & Mn & $\mathbf{Z n}$ & $\mathrm{Cu}$ & \multirow{2}{*}{ M.O (\%) } & \multirow{2}{*}{ pH } & \multirow{2}{*}{$\operatorname{EC}\left(\mathrm{dSm}^{-1}\right)$} \\
\hline & & & & $\overline{(m g ~ k q}$ & & & & & & & & \\
\hline $\mathrm{VC}$ & 6.26 & 38.3 & 223.0 & 39.8 & 1.6 & 21.2 & 4.3 & 1.3 & 0.9 & 8.5 & 8.1 & 3.6 \\
\hline SB & 7.14 & 40.5 & 234.4 & 36.8 & 1.0 & 0.8 & 9.5 & 4.7 & 1.2 & 7.5 & 8.7 & 7.3 \\
\hline $\mathrm{MC}$ & 4.33 & 61.7 & 220.5 & 66.5 & 1.6 & 6.7 & 5.4 & 4.6 & 1.3 & 4.0 & 8.5 & 7.1 \\
\hline AS & 8.17 & 37.4 & 319.8 & 26.7 & 2.2 & 8.6 & 2.7 & 2.5 & 1.1 & 1.5 & 7.9 & 2.1 \\
\hline
\end{tabular}

Analyses were performed at the laboratory of the farming cooperative of the Comarca Lagunera. $\mathrm{VC}=$ vermicompost; $\mathrm{SB}=$ solarized bovine manure; $\mathrm{MC}=$ mineralized compost; $\mathrm{AS}=$ agricultural soil. 
Table 2. Comparison of the fruit's mean weight, soluble solids, equatorial and polar diameters of tomatoes produced in organic substrates under shade net conditions. Coahuila, Mexico, Technological Institute of Torreon, 2014.

\begin{tabular}{lcccc}
\hline \multirow{2}{*}{ Treatments } & \multirow{2}{*}{ Weight (g) } & \multirow{2}{*}{$\begin{array}{c}\text { Soluble solids } \\
\text { ('Brix) }\end{array}$} & \multicolumn{2}{c}{ Diameter (cm) } \\
\cline { 4 - 6 } & & & Polar & Equatorial \\
\hline S:VC (80:20) & $270 \mathrm{ab}^{\dagger}$ & $4.07 \mathrm{a}$ & $6.230 \mathrm{ab}$ & $4.17 \mathrm{a}$ \\
S:SB (80:20) & $140 \mathrm{~b}$ & $3.82 \mathrm{a}$ & $5.875 \mathrm{ab}$ & $4.05 \mathrm{a}$ \\
S:SB:AS (80:15:05) & $103 \mathrm{~b}$ & $3.07 \mathrm{a}$ & $5.312 \mathrm{bc}$ & $4.05 \mathrm{a}$ \\
S:VC:AS (80:15:05) & $360 \mathrm{a}$ & $4.77 \mathrm{a}$ & $5.400 \mathrm{bc}$ & $4.21 \mathrm{a}$ \\
S:MC (80:20) & $390 \mathrm{a}$ & $3.85 \mathrm{a}$ & $6.475 \mathrm{a}$ & $4.57 \mathrm{a}$ \\
S (100\%) & $283 \mathrm{ab}$ & $4.82 \mathrm{a}$ & $4.725 \mathrm{c}$ & $4.48 \mathrm{a}$ \\
\hline CV (\%) & 35.59 & 5.59 & 11.47 & 11.50 \\
\hline
\end{tabular}

different letters inside each column indicate a significant statistical difference (Tukey; $\mathrm{P} \leq 0.05) . \mathrm{CV}=$ coefficient of variation. $\mathrm{S}=$ sand; $\mathrm{VC}=$ vermicompost; $\mathrm{SB}=$ solarized bovine manure; $\mathrm{AS}=$ agricultural soil; $\mathrm{MC}=$ mineralized compost.

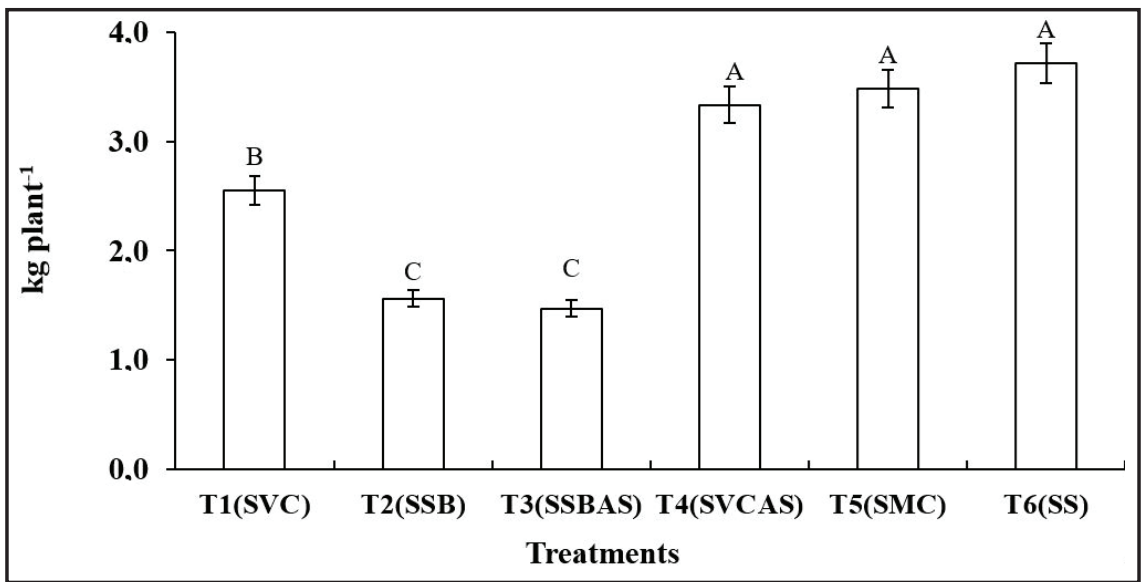

Figure 1. Yield of tomatoes produced in planters with organic substrates mixtures in shade net system. Different letters inside each column indicate significant statistical difference (Tukey; $\mathrm{P} \leq 0.05$ ). Lines over bars represent standard error for each treatment's mean. $\mathrm{S}=$ sand; $\mathrm{VC}=$ vermicompost $\mathrm{SB}=$ solarized bovine manure; $\mathrm{AS}=$ agricultural soil; $\mathrm{MC}=$ mineralized compost. Coahuila, Mexico, Technological Institute of Torreon, 2014.

relied on the type of substrate (Tukey, $\mathrm{P} \leq 0.05)$. Phenolic content of the tomato produced in this study was 36.0 to 56.94 mg equivalent of gallic acid per $100 \mathrm{~g}$ in fresh weight for T1 (SVC/80:20) and T5 (S:MC, 80:20), respectively. That is to say, it increased by $56 \%$ when mineralized compost was used, with respect to vermicompost. However, the Steiner solution (T6), vermicompost with agricultural soil (T4), and solarized manure plus soil (T3) treatments were statistically equal (Figure 2).

Results obtained in this work were higher than those reported by Zapata $e t$ al. (2007), who mention a $17.38 \pm 4.40$ and $18.91 \pm 5.75 \mathrm{mg}$ gallic acid/100 $\mathrm{g}$ phenolic content in fresh tomato in ripeness and commercial phase.
For this matter, it is stated that some fruits and vegetables contain certain chemical compounds (phytochemical) like phenols, which are believed to be related to the antioxidant synthesis as response to the subjection of the plant to oxidation stress, so substances are accumulated as a defense method. Oliveira et al. (2013) state the fruits from organic agriculture have a higher stress level, which along with the limitation of the nitrogen available in soil, make fruits $40 \%$ smaller. On the other hand, vitamin $\mathrm{C}$ and phenol concentrations were $55 \%$ and $139 \%$ higher than in conventional cultivation of tomatoes.

In this study, the greatest antioxidant capacity was obtained in treatment 4
(S:VC:AS, 80:15:05) being statistically equal to treatment 1 but statistically different to other treatments. Values found varied from 122 (T2) to 480 (T4) $\mu \mathrm{M}$ equivalent in Trolox/100 g FW ranges (Figure 2). Sahlin et al. (2004) reported that the amount of antioxidant molecules in tomatoes can be affected by several factors such as geographic location and environmental factors during cultivation, harvest time, storage conditions and fruit ripeness. Besides, the plants' response to stressing environmental conditions, like in organic production systems, generate defense mechanisms including antioxidants production (Winter \& Davis, 2006).

The fruits' color is an important feature to the consumer's eye. In case of tomato, lycopene is responsible for its red color. Bio-synthesis of its pigmentation is genetically controlled and is affected by the environment (Brandt et al., 2006). In this study, lycopene content of harvested tomatoes depended on the type of substrate, that is, ANOVA showed significant differences $(\mathrm{P} \leq 0.05)$. For this variable, two colors were evaluated (yellow and red) corresponding to two ripeness phases.

According to observations, the lycopene content on fruits was in average, $32 \%$ higher in the red colored ones than in the yellow ones, with 3.12 and $2.24 \mathrm{mg}$ lycopene values, $100 \mathrm{~g} \mathrm{pulp}^{-1}$, respectively. For red color, treatment T5 presented the highest value, followed by treatment $\mathrm{T} 1$, treatment $\mathrm{T} 4$ and treatment T3; control treatment (T6) presented a value of $2.62,34 \%$ lower than the highest treatment (T5).

It is worth noting that in the two analyzed colors, the control treatment (T6) obtained the lowest lycopene values (Figure 3). The amount of pigment found in this work was lower compared to the values reported by Gaspar-Peralta et al. (2012), with 9.6 to $16.8 \mathrm{mg} / 100$ $\mathrm{g}$ wet base and 4.83 to $14.1 \mathrm{mg}$ wet base in peel, reported by George et al. (2004). Arias et al. (2000), mention that the lycopene concentration increases with the ripeness of tomatoes, when chloroplasts change to chromoplasts and lycopene synthesis increases 


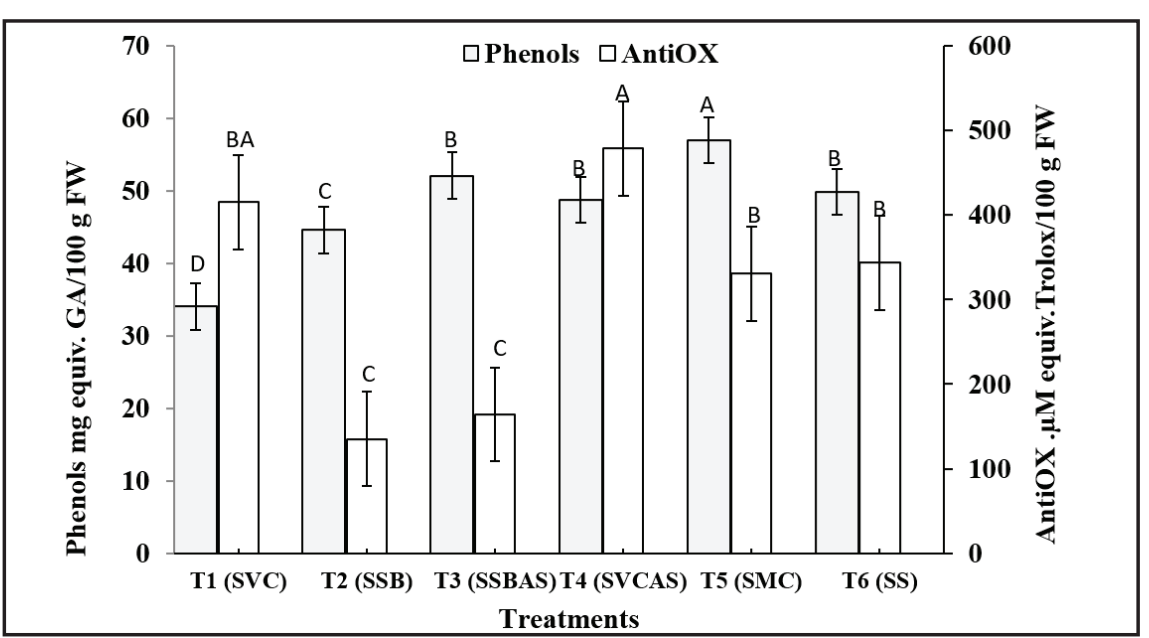

Figure 2. Average phenols content and average antioxidant capacity in tomato fruits produced in planters with organic substrate mixtures in shade net conditions. Different letters inside each column indicate a significant statistical difference (Tukey; $\mathrm{P} \leq 0.05$ ). Lines over bars represent standard error for each treatment's mean. $\mathrm{S}=$ sand; $\mathrm{VC}=$ vermicompost; $\mathrm{SB}=$ solarized bovine manure; $\mathrm{AS}=$ agricultural soil; $\mathrm{MC}=$ mineralized compost. Coahuila, Mexico, Technological Institute of Torreon, 2014.

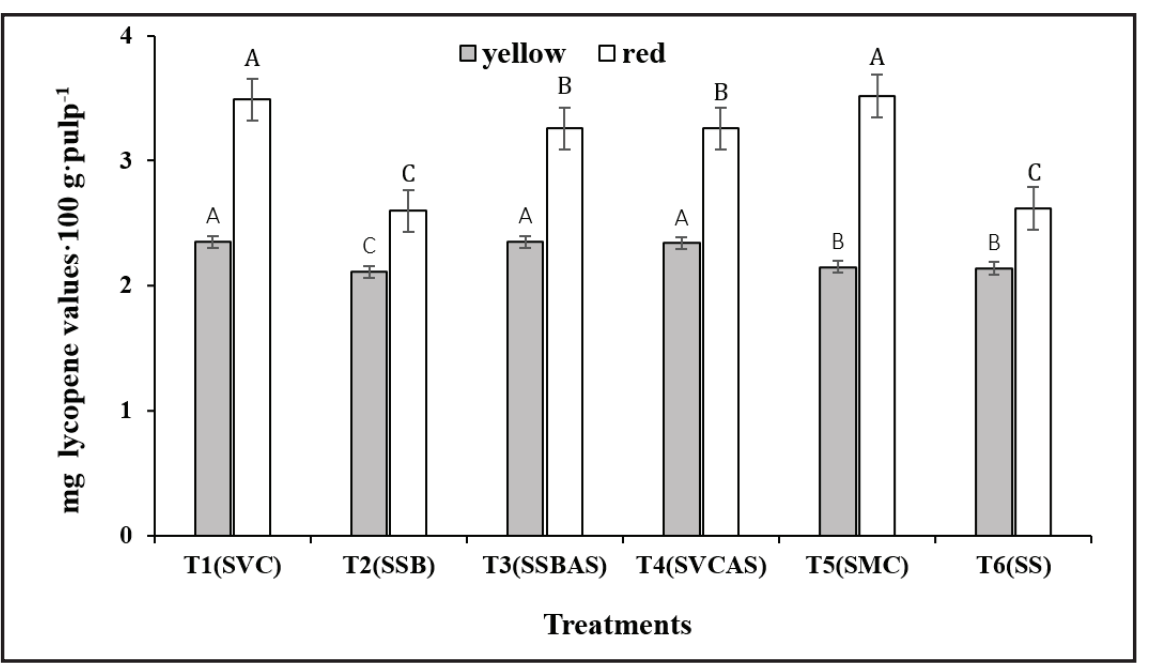

Figure 3. Lycopene colors, yellow and red, in tomatoes produced in planters with organic substrates in shade net conditions. Different letters inside each column indicate a significant statistical difference (Tukey; $\mathrm{P} \leq 0.05$ ). Lines over bars represent standard error for each treatment's mean. $\mathrm{S}=$ sand; $\mathrm{VC}=$ vermicompost; $\mathrm{SB}=$ solarized bovine manure; $\mathrm{AS}=$ agricultural soil; $\mathrm{MC}=$ mineralized compost. Coahuila, Mexico, Technological Institute of Torreon, 2014.

causing red coloring. Luna-Guevara \& Delgado-Alvarado (2014), state that lycopene content in tomatoes depends mainly on genetic (vegetable material), environmental (mineral nutrients, soil conditions, growing periods, etc.) and ripeness factors. Oliveira et al. (2013), state that among all factors that seem effective in enhancing the concentrations of phytochemicals in fruits and vegetables, stress emerges as especially promising.

With sand plus soil and vermicompost
3.12 and 2.24 mg lycopene 100 g pulp $^{-1}$ values, respectively. For the red ones, treatment $\mathrm{T} 5$ showed the highest value (3.52) and in yellow T1 reported 2.35, while T2 presented the lowest values for both colors. Organic fertilizers based on SVC can induce good amounts of lycopene in fruits of both colors, as well as improve phenols and antioxidant capacity.

\section{ACKNOWLEDGEMENTS}

To the National Institute of Technology of Mexico (TecNM), for funding the project.

\section{REFERENCES}

ABDEL-GHANY, AM; PIETRO, P; IBRAHIM, AH; ABDULlaH, A; ABDULlah, I; MOHAMED, S. 2015. Radiometric characterization, solar and thermal radiation in a greenhouse as affected by shading configuration in an arid climate. Energies 8:13928-13937.

ALI, HM; ISMAIL, GSM. 2014. Tomato fruit quality as influenced by salinity and nitric oxide. Turk Journal of Botany 38:122-129.

ANGUELOVA, T; WARTHERSEN, J. 2000. Degradation of lycopene, $\alpha$-carotene and $\beta$-carotene during lipid peroxidation. Journal of Food Science 65: 71-75.

ANSORENA-MINER, J. 1994. Sustratos: Propiedades y caracterización. Madrid: Ediciones Mundi-Prensa. 172 p.

ARIAS, RL; TUNG, CHL; LOGENDRA, L; JANES, H. 2000. Correlation of lycopene measured by HPLC with the L*, a*, b* colour readings of a hydroponic tomato and the relationship of maturity with colour and lycopene content. Journal of Agricultural and Food Chemistry 48:1697-1702.

BRANDT, S; PÉK, Z; BARNA, E; LUGASI, A; HELYES, L. 2006. Lycopene content and color of ripening tomatoes as affected by environmental conditions. Journal of Science and Food Agriculture 86: 568-572.

DE LA CRUZ-LÁZARO, E; ESTRADA, BMA; ROBLEDO, TV; OSORIO, OR; MÁRQUEZ, HC; SÁNCHEZ, HR. 2009. Tomato Production in a Greenhouse with compost and vermicompost as substrate. Universidad y Ciencia 25: 59-67.

DE LA CRUZ-LÁZARO, E; OSORIO, OR; MARTÍNEZ, ME; LOZANO DEL RÍO, JA; GÓMEZ, VA; SÁNCHEZ, HR. 2010. Use of compost and vermicompost in the production of organic tomato in a Greenhouse. Interciencia 35: 363-368.

ESPARZA, RJR; STONE, MB; STUSHNOFF, CE; PILON, SP; KENDALL, A. 2006. Effects of ascorbic acid applied by two hydrocooling methods on physical and chemical properties 
of green leaf lettuce stored at $5^{\circ} \mathrm{C}$. Journal of Food Science 71: S270-S276.

GASPAR-PERALTA, P; CARRILLO, RJC; CHÁVEZ, SJL; VERA, GAM; PÉREZ, LI. 2012. Variation of agronomic features and lycopene in advanced tomato lines (Solanum lycopersicum L.). Journal Phyton 81: 15-22.

GEORGE, B; KAUR, C; KHURDIYA, DS; KAPOOR, HC. 2004. Antioxidants in tomato (Lycopersicon esculentum) as a function of genotype. Food Chemistry 84: 45-51.

HELYES, L; LUGASI, A. 2006. Formation of certain compounds having technological and nutritional importance in tomato fruits during maturation. Acta Alimentaria 35: 183-193.

KRAUSS, S; SCHNITZLER, WH ; GRASSMANN, J; MARKUS, WM. 2006. The influence of different electrical conductivity values in a simplified recirculating soilless system on inner and outer fruit quality characteristics of tomato. Journal of Agricultural and Food Chemistry 54: 441-448.

LUNA-GUEVARA, ML; DELGADOALVARADO, A. 2014. Importance, contribution and stability of antioxidants in fruits and tomato products (Solanum lycopersicum L.). Avances en Investigación Agropecuaria 18:51-66.

MÁRQUEZ, HC; CANO, RP; RODRÍGUEZ, DN. 2008. Use of organic substrates for tomato production in a greenhouse. Agricultura Técnica en México 34: 69-74.

MAYEAUX, M; XU, Z; KING, JM; PRINYAWIWATKUL, W. 2006. Effects of cooking conditions on the lycopene content in tomatoes. Journal of Food Science 71: C461-C464.

MÖLLER, M; ASSOULINE, S. 2007. Effects of a shading screen on microclimate and crop water requirements. Irrigation Science 25: 171-181. MOLYNEUX, P. 2004.The use of the stable free radical diphenylpicrylhydrazyl (DPPH) for estimating antioxidant activity. Songklanakarin Journal of Science and Technology 26: 211219.

MANI, CH; SHANMUGARAJ, BM; SRINIVASAN, B; RAMALINGAM, S. 2012. Influence of genotypic variations on antioxidant properties in different fractions of tomato. Journal of Food Science 77: C1174-C1178.

MORENO, RA; LOPEZ, AFJ; FIGUEROA, MU; RODRÍGUEZ, DN; VASQUEZ, AJ; REYES, CJL; CANO, RP; REYES, VMH. 2012. Tomato production in sand: vermicompost mixtures compared with sand and nutritive solution. Basic Research Journal of Agricultural Science 1: 19-26.

OLIVEIRA, AB; MOURA, CFH; GOMESFILHO, E; MARCO, CA; URBAN, L; MIRANDA, MRA. 2013. The impact of organic farming on quality of tomatoes is associated to increased oxidative stress during fruit development. PLoS ONE 8: e56354. Doi: 10.1371/journal.pone.0056354.

ORTEGA-MARTÍNEZ, LD; SÁNCHEZ, OJ; OCAMPO, MJ; SANDOVAL, CE; SALCIDO, RBA; MANZO, RF. 2010. Effects of different substrates on the growth and yield of tomatoes (Lycopersicum esculentum Mill) bajo condiciones de invernadero. Ra Ximhai. 6: 339-346.

SAHLIN, E; SAVAGE, GP; LISTER, CE. 2004. Investigation of the antioxidant properties of tomatoes after processing. Journal of Food Composition and Analysis 17: 635-647.

Secretariat of Agriculture, Livestock, Rural Development, Fisheries, and Food Service agency for commercialization and development of agriculture and livestock markets (SAGARPA-ASERCA) 2008. Document on conditions of use of the Mexican official norm for supreme quality in tomatoes. BANCOMEXT. ASERCA. PC-020-2005. Available at http://www. mexicocalidadsuprema.org/assets/galeria/ PC_020_2005_Tomate.pdf

Secretariat of Agriculture, Livestock, Rural Development, Fisheries and Food (SAGARPA) 2015. Information Service for agri-foods and fisheries (SIAP). Atlas Agroalimentario 2015. First Edition. ISBN: 978-607-9350-05-5. Mexico City.

Statistical Analysis System (SAS). 2009. SAS/ STAT ${ }^{\circledR}$ 9.2. Users's guide release. Cary: SAS Institute Inc., USA.

STEINER, A.A (1984). The universal nutrient solution. Proc. 6th Int. cong. on soil-less culture. ISOSC. Lunteren, Holanda, pp. 633-649.

WINTER, CK; DAVIS, SF. 2006. Organic foods. Journal of Food Science 71: 117-124.

WU, M; KUBOTA, CH. 2008. Effects of high electrical conductivity of nutrient solution and its application timing on lycopene, chlorophyll and sugar concentrations of hydroponic tomatoes during ripening. Scientia Horticulturae 116: 122-129.

ZHAI, Y, YANG, Q, HOU, M. 2015. The effects of saline water drip irrigation on tomato yield, quality, and blossom-end rot incidence a 3 a case study in the south of china. PLoS ONE 10: e0142204. Doi: 10.1371/journal. pone. 0142204 .

ZAPATA, LM; GERARD, L; DAVIES, C; SCHVAB, MDC. 2007. Estudio de los componentes antioxidantes y actividad antioxidante en tomates. Ciencia, Docencia y Tecnología 35: 173-193. 